\title{
Effect of pruning and plant spacing on the growth of cherry rootstocks and their influence on stem water potential of sweet cherry trees
}

\author{
B. Gonçalves, A. Santos, A. P. Silva, J. Moutinho-Pereira \& J. M. G. Torres- \\ Pereira
}

To cite this article: B. Gonçalves, A. Santos, A. P. Silva, J. Moutinho-Pereira \& J. M. G. TorresPereira (2003) Effect of pruning and plant spacing on the growth of cherry rootstocks and their influence on stem water potential of sweet cherry trees, The Journal of Horticultural Science and Biotechnology, 78:5, 667-672, DOI: 10.1080/14620316.2003.11511682

To link to this article: http://dx.doi.org/10.1080/14620316.2003.11511682

曲 Published online: 07 Nov 2015.

Submit your article to this journal ¿

Џlll Article views: 7

Q View related articles $₫$

Citing articles: 1 View citing articles $ک 7$ 


\section{Effect of pruning and plant spacing on the growth of cherry rootstocks and their influence on stem water potential of sweet cherry trees}

\section{By B. GONÇALVES ${ }^{1 *}$, A. SANTOS ${ }^{2}$, A. P. SILVA ${ }^{2}$, J. MOUTINHO-PEREIRA $^{1}$ and} J. M. G. TORRES-PEREIRA ${ }^{1}$

${ }^{1}$ Department of Biological and Environmental Engineering/CETAV, University of Trás-os-Montes e Alto Douro, Apartado 1013, 5001-911 Vila Real, Portugal

${ }^{2}$ Department of Plant Science and Agricultural Engineering, CECEA, University of Trás-os-Montes e Alto Douro, Apartado 1013, 5001-911 Vila Real, Portugal

(e-mail: bertag@utad.pt)

(Accepted 16 April 2003)

\section{SUMMARY}

The aims of this work are to describe the effects of pruning and planting density on growth and water relations of ungrafted and grafted sweet cherry trees. A trial with cherry rootstocks 'Prunus avium', 'CAB 11E', 'Maxma 14', 'Gisela 5' and 'Edabriz' was begun in 1997. Pruning severities were applied to the rootstocks $(0,30,60$ and $90 \%$ of the vegetative growth was removed corresponding to P1, P2, P3 and P4 treatments, respectively) after planting to two plant spacings $(\mathrm{S} 1=0.25 \times 1.0 \mathrm{~m}$ and $\mathrm{S} 2=0.45 \times 1.5 \mathrm{~m})$. Canopy, root growth and leaf water potential $\left(\psi_{\text {leaf }}\right)$ were quantified throughout the growing season. Pruning significantly affected root length and root weight of the rootstocks. Uncut plants (P1) showed a heavier and expanded root biomass $(231 \mathrm{~g}$ and $108 \mathrm{~m})$ than the intensively pruned plants (P4) $(187 \mathrm{~g}$ and $75 \mathrm{~m})$. The greater root biomass was obtained with the spacing/pruning combination, S1/P1 (285 g), and the smaller with S1/P4 $(180 \mathrm{~g})$ and S2/P4 $(176 \mathrm{~g})$. $\psi_{\text {leaf }}$ varied significantly between the rootstocks and plant spacing but not with pruning. 'Maxma 14' and 'P. avium' attained the lowest values of midday $\psi_{\text {leaf }},-2.28$ and -2.04 $\mathrm{MPa}$, but the highest values of predawn $\psi_{\text {leaf }},-0.29$ and $-0.25 \mathrm{MPa}$, respectively. Generally, with high density (S1), the rootstocks exhibited lower predawn and midday $\psi_{\text {leaf }}$. In 1998, cultivars 'Burlat', 'Summit' and 'Van' were grafted onto rootstocks and a trial was installed in 1999 . Predawn and midday stem water potential $\left(\psi_{\text {stem }}\right)$ on cherry trees, measured in 2002, were affected significantly by the rootstock/genotype combination. Cultivars grafted on ' $P$. avium' and 'Maxma 14' showed the less negative midday $\psi_{\text {stem }},-1.36$ and $-1.42 \mathrm{MPa}$ respectively, so these rootstock genotypes perhaps induced a higher drought resistance to the scion. Recorded data show that the scion-rootstock interaction with regard to production performance under water deficits may be an important consideration in cherry tree planting strategies.

$\mathbf{T}$ ree size plays a central role in orchard management and production of quality fruit. Some authors have reported that scion vigour is controlled by various means: pruning, nutrition and/or rootstocks (Faust, 1989; Webster, 2001). Chalmers et al. (1983) stated that plant spacing and competition for water can interact synergistically to reduce vegetative growth.

The growth of woody perennial species is affected by rootstocks, scions and their resulting interactions (Tubbs, 1976, 1977, 1980; Iacono et al., 1998). Growth and physiological characteristics were evaluated in autografted and reciprocally grafted plants of Prunus avium $\times$ Prunus pseudocerasus 'Colt' and $P$. cerasus 'Meteor'. Rootstock influenced growth, morphology (leaf area:root surface area) and specific leaf area, and physiological (net assimilation rate) characteristics of grafted plants (Ranney et al., 1991a). Düring (1994) and Iacono et al. (1998), concluded that rootstock genotype induced drought resistance in the scion in grafted grapevines.

\footnotetext{
*Author for correspondence.
}

In a study by Schmitt et al. (1989), leaf water potential $\left(\psi_{\text {leaf }}\right)$ was determined on cherry trees and was most negative in $P$. cerasus seedlings, followed by 'Sam' on ' $F$ $12 / 1$ ', 'Sam' on ' $P$. cerasus' clones and 'Sam' on ' $P$. acida'. Measurements of stomatal conductance $\left(g_{s}\right), \psi_{\text {leaf }}$ and $\psi_{\text {stem }}$ on apple, grapevine and nectarine trees under several irrigation treatments from early morning to midafternoon showed that $\psi_{\text {stem }}$ was more closely correlated with $g_{s}$ than $\psi_{\text {leaf }}$ was correlated with $g$, and rates of shoot growth, with shoot growth essentially stopping once $\psi_{\text {stem }}$ with $g_{s}$ (Naor, 1998). Centritto et al. (1999) observed that $\mathrm{g}_{\mathrm{s}}$ of cherry seedlings was highly correlated with soil water status. In a combined rootstock-irrigation trial on cherry 'Bing', $\psi_{\text {stem }}$ fell to between -1.5 and $-1.7 \mathrm{MPa}$ (Shackel et al., 1997).

Information on the effects of rootstock on growth, drought resistance and water relations of cherry trees are incomplete, so the two aims of this study were to determine the influence of pruning and plant spacing on $\psi_{\text {leaf }}$, canopy and root growth in cherry rootstocks throughout the growing season and to determine the effect of rootstock genotype on $\psi_{\text {stem }}$ of four year old cherry cultivars, after grafting. 


\section{MATERIALS AND METHODS}

\section{Experimental trials}

The trials were set up at Vila Real, in the north-east of Portugal, at $470 \mathrm{~m}$ a.s.l., $41^{\circ} 19^{\prime} \mathrm{N}$ and $7^{\circ} 44^{\prime} \mathrm{W}$. According to the Thornthwaite classification, the regional climate is humid, mesotermic, with high deficit of water in the summer, and with moderate thermic efficiency in summer $\left(\mathrm{C}_{2} \mathrm{~B}^{\prime}{ }_{2} \mathrm{~s}_{2} \mathrm{~b}^{\prime}{ }_{4}\right)$ (Thornthwaite, 1948). The average annual rainfall is about $1,100 \mathrm{~mm}$, mainly from October to April. Warmest months are July/August and coldest are December/January, with average daily temperatures of $21-22^{\circ} \mathrm{C}$ and $6-7^{\circ} \mathrm{C}$, respectively. Mean annual sunshine values over a 33 year period are $2,392 \mathrm{~h}$, the lowest monthly values (100 h) occurring in December and the highest (342 h) in July (Figure 1).

Trial 1: In February 1997 an experimental plot of five cherry rootstocks with different vigour: 'Prunus avium', 'CAB 11E', 'Maxma 14', 'Gisela 5' and 'Edabriz' was planted. Different pruning severities were applied to 2000 stools (400 plants per rootstock): 0, 30, 60 and 90\% of the vegetative growth was removed, corresponding to $\mathrm{P} 1, \mathrm{P} 2, \mathrm{P} 3$ and $\mathrm{P} 4$ treatments, respectively, after planting to two plant spacings: $\mathrm{S} 1=0.25 \times 1.0 \mathrm{~m}$ and $\mathrm{S} 2=0.45 \times$ $1.5 \mathrm{~m}$. The soil is a Dystrochrept Silt Loamy, with $\mathrm{pH} 5.4$ and an organic matter content of $1.45 \% ; \mathrm{P}_{2} \mathrm{O}_{5}$ and $\mathrm{K}_{2} \mathrm{O}$ contents are 63 and $348 \mathrm{mg} \mathrm{kg}$, respectively.

Trial 2: Sweet cherry (Prunus avium) 'Burlat', 'Summit' and 'Van' were grafted by chip-budding in September onto those five rootstocks. The scions were transplanted to the orchard in February 1999, in a randomized complete block design in a trial where the trees have $5 \mathrm{~m}$ between rows and in-row spacings vary according to the relative vigour of the rootstock; with a minimum of $2.5 \mathrm{~m}$ and a maximum of $5.5 \mathrm{~m}$ for 'Edabriz' and ' $P$. avium', respectively. In this phase of the orchard life, these spacings do not affect tree behaviour. The soil is a deep $(>100 \mathrm{~cm})$ Sandy Loam Dystric Arid Antherosol, pH 4.7 with an organic matter content of $1.5 \%$, high content of fine sand $(0.2-0.02 \mathrm{~mm})$, high content of $\mathrm{K}_{2} \mathrm{O}$ (150-200 mg kg) and medium on $\mathrm{P}_{2} \mathrm{O}_{5}(50-100 \mathrm{mg} \mathrm{kg})$.

\section{Canopy and root growth}

From each combination $(5$ rootstocks $\times 4$ Pruning severities $\times 2$ Spacings), three plants were recorded to

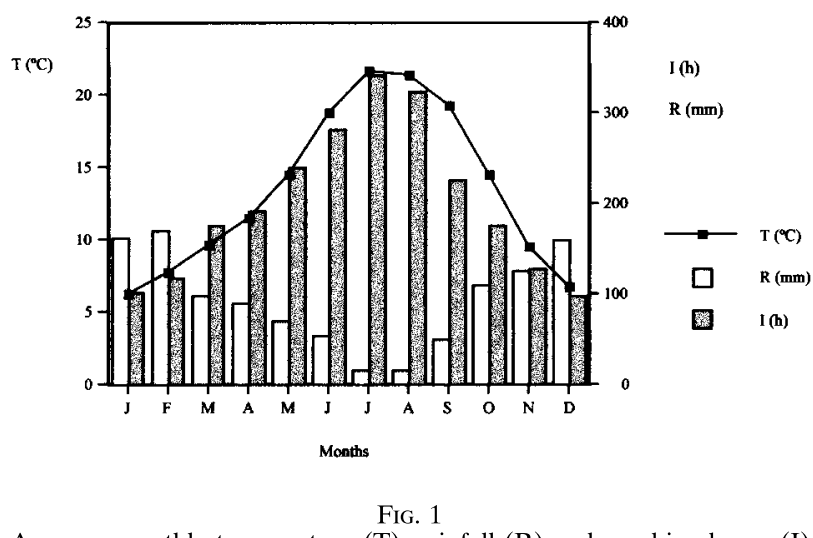

Average monthly temperature (T), rainfall (R) and sunshine hours (I) for Vila Real (period 1961-90) evaluate canopy and root growth. The trees were carefully removed from the soil using water and an iron bar, were enclosed in a plastic bag and immediately analysed. Leaf area was estimated using a portable area meter (CI-201 Portable Leaf Area Meter-CID, USA) and fine roots (root diameter $<2 \mathrm{~mm}$ ) extension was measured with a 'Comair Root Length Scanner' (Commonwealth Aircraft Corporation Limited, Australia). When this value was higher than $50 \mathrm{~m}$, to obtain a more rigorous determination according to the instruction manual, the following equation was used: $\mathrm{A}=-0.2246+0.9655 \mathrm{E}+0.00123 \mathrm{E}^{2}$, where $\mathrm{E}$ was the root length scan. All the shoots and roots were measured and weighed.

\section{Leaf and stem water potential}

Pre-dawn and midday leaf water potentials of the cherry rootstocks were measured on 25 July and 19 August 1997, using a pressure chamber (ELE International, UK), according to the method described by Scholander et al. (1965). The $\psi_{\text {leaf }}$ was measured on three fully expanded healthy leaves on sun-exposed shoots per combination. To avoid evaporative loss, leaves were enclosed in a plastic bag just prior to cutting the petiole.

Predawn and midday stem water potentials of grafted cherry trees were determined on 21 June 2002. Several field studies (Garnier and Berger, 1985; McCutchan and Shackel, 1992; Naor and Wample, 1994; Naor et al., $1995)$ have showed that midday $\psi_{\text {stem }}$ was more closely correlated with soil water availability than midday $\psi_{\text {leaf }}$. So, in our study, $\psi_{\text {stem }}$ was measured on shaded leaves taken from inside the canopy; leaves were placed in a plastic bag covered with aluminium foil for at least 90 min before measurements were taken, to allow $\psi_{\text {leaf }}$ to equilibrate with $\psi_{\text {stem }}$. Each measurement period included four records of $\psi_{\text {stem }}$ by scion-rootstock interaction.

\section{Statistics}

The data were analysed using analysis of variance by Super ANOVA (1.11 Abacus Concepts Inc., 1991) program. Mean separations were made using Fisher's Protected LSD Test $(P=0.05)$, designed to allow all possible linear combinations of group means to be tested.

The Discriminant Canonical Analysis (DCA) was obtained using the STATISTICA program (Statsoft, 1995). DCA is used to determine which variables discriminate between two or more naturally occurring groups (Hair et al., 1995). The method used was Stepwise Discriminant Function Analysis, which "builds" a model of discrimination step-by-step, reviewed all variables and evaluate which one will contribute most to the discrimination between groups (SPSS, 1997). This method use the Wilks's lambda statistic for the overall discrimination that is computed as the ratio of the determinant (det) of the within-groups variance/covariance matrix over the determinant of the total variance covariance matrix:

$$
\text { Wilks's lambda }=\operatorname{det}(\mathrm{W}) / \operatorname{det}(\mathrm{T})
$$


TABLE I

Vegetative parameters measured on cherry rootstocks in the growing season. Values are the mean $\pm S D(n=24)$. Means flanked by the same letter are not significantly different at $\mathrm{P}<0.05$ (Fisher's test)

\begin{tabular}{|c|c|c|c|c|c|}
\hline Vegetative characteristics & 'P. avium' & CAB 11E & Maxma 14 & Gisela 5 & Edabriz \\
\hline Fine $\operatorname{roots}^{\S}(\mathrm{m})$ & $69.9 \pm 66.3 \mathrm{a}$ & $204.7 \pm 80.9 \mathrm{~b}$ & $33.3 \pm 15.6 \mathrm{a}$ & $52.7 \pm 21.2 \mathrm{a}$ & $42.2 \pm 19.0 \mathrm{a}$ \\
\hline Root length (m) & $73.0 \pm 68.3 \mathrm{a}$ & $214.0 \pm 82.7 b$ & $34.2 \pm 16.3 \mathrm{a}$ & $54.5 \pm 21.4 \mathrm{a}$ & $44.6 \pm 19.7 \mathrm{a}$ \\
\hline Root weight (g) & $160.5 \pm 140.3 b$ & $583.8 \pm 181.7 \mathrm{c}$ & $41.9 \pm 31.4 \mathrm{a}$ & $113.7 \pm 37.1 \mathrm{ab}$ & $81.9 \pm 42.4 \mathrm{a}$ \\
\hline Stem length $(\mathrm{cm})$ & $123.0 \pm 50.4 \mathrm{~b}$ & $140.2 \pm 24.7 \mathrm{bc}$ & $122.8 \pm 30.9 \mathrm{ab}$ & $156.0 \pm 22.7 \mathrm{c}$ & $102.6 \pm 31.6 \mathrm{a}$ \\
\hline Stem diameter $(\mathrm{mm})$ & $13.1 \pm 5.1 \mathrm{~b}$ & $19.2 \pm 3.3 \mathrm{c}$ & $8.0 \pm 3.0 \mathrm{a}$ & $13.5 \pm 3.5 \mathrm{~b}$ & $11.7 \pm 3.4 \mathrm{~b}$ \\
\hline Branch length $(\mathrm{cm})$ & $91.1 \pm 65.4 \mathrm{a}$ & $654.0 \pm 300.9 \mathrm{c}$ & $139.3 \pm 103.5 \mathrm{ab}$ & $317.8 \pm 174.9 \mathrm{~b}$ & $200.8 \pm 111.7 \mathrm{ab}$ \\
\hline Canopy fresh weight $(\mathrm{g})$ & $184.1 \pm 181.7 \mathrm{a}$ & $490.3 \pm 187.9 b$ & $92.7 \pm 78.4 \mathrm{a}$ & $209.0 \pm 89.6 \mathrm{a}$ & $125.4 \pm 78.3 \mathrm{a}$ \\
\hline No. leaves & $55.8 \pm 29.5 \mathrm{a}$ & $228.6 \pm 79.3 \mathrm{c}$ & $71.7 \pm 41.4 \mathrm{ab}$ & $109.3 \pm 37.4 \mathrm{~b}$ & $122.5 \pm 76.5 \mathrm{~b}$ \\
\hline Leaf area $\left(\mathrm{m}^{2}\right)$ & $0.5 \pm 0.2 \mathrm{a}$ & $2.2 \pm 0.8 \mathrm{~b}$ & $0.3 \pm 0.2 \mathrm{a}$ & $0.5 \pm 0.2 \mathrm{a}$ & $0.4 \pm \quad 0.2 \mathrm{a}$ \\
\hline
\end{tabular}

${ }^{\S}$ Fine roots $(\varnothing<2 \mathrm{~mm}$ diameter $)$.

The $F$ value for a variable indicates its statistical significance in the discrimination between groups, that is, it is a measure of the extent to which a variable makes a unique contribution to the prediction of group membership.

\section{RESULTS AND DISCUSSION \\ Canopy and root growth}

All the vegetative parameters measured differed significantly $(P<0.001)$ between the five rootstocks (Table I). 'CAB 11E' displayed the longest and heaviest root system compared with the other rootstocks, essentially composed of fine roots (root diameter $<2 \mathrm{~mm}$ ). The root system of 'Edabriz' was mainly composed of roots thinner than $2 \mathrm{~mm}$, but were nevertheless well fixed. Edin (1993) and Kappel (1993) also verified that under adverse climatic conditions, such as wind or heavy rain, such roots were brittle and that they cannot tolerate drought, because these roots include apical regions where cellular growth is rapid and, for this reason, are sensitive.

Pruning significantly affected total root length and fine root length $(P<0.01)$ and root weight $(P<0.05)$ of cherry rootstocks. Uncut plants $(\mathrm{P} 1)$ showed a higher root growth $(108 \mathrm{~m})$ than the intensively cut plants (P4) $(75 \mathrm{~m})$, where there was a drastic reduction both in length and weight, i.e., the more the rootstocks were cut at planting the less their root system developed (Figure 2). Ranney et al. (1989), observed that the pruning (dormant shoots pruned to $20 \mathrm{~cm}$ in length) of 'Colt' trees had no effect on the leaf area:root area ratio. Asamoah and Atkinson (1985) also verified that root pruning reduced root, leaf and stem weight in 'Colt' cherry rootstocks. The growth of the rootstocks is important, because the volume of soil explored by the roots defines the amount of water available from a given soil volume. Available soil moisture, i.e. the water that can be extracted by roots, held at a water potentials ranging between -0.1 and $-1.5 \mathrm{MPa}$, which approximate field water-holding capacity and the permanent wilting percentage, respectively (Kramer, 1983). However, it should be stressed that the rate of root growth of the majority of plant species declines as the soil moisture increases above the soil water-holding capacity, due to a reduction in soil aeration (hypoxia). In this rhizosphere condition, the respiratory quotient $\left(\mathrm{RQ}=\mathrm{mol} \mathrm{CO}_{2} / \mathrm{mol}\right.$ $\mathrm{O}_{2}$ ) becomes greater than 1 , root growth stops and root tips entering the low-oxygen zones die off (Larcher, 1995).
The greatest growth of the root system was obtained with the spacing/pruning combination S1/P1 (113 m) and the less favourable ones were obtained with S1/P4 (76 $\mathrm{m})$ and S2/P4 (74 m).

The Discriminant Canonical Analysis (DCA) done with all vegetative characteristics measured on rootstocks showed that canopy fresh weight (CFW) had a large discriminating effect, demonstrated by the higher $\mathrm{F}$ value $(\mathrm{F}=110.05)$, contrasting with the other lower $\mathrm{F}$ values corresponding to the other vegetative variables (Table II). Figure 3 shows that the two $P$. cerasus clones, CAB $11 \mathrm{E}$ and Edabriz, had more vegetative affinity and 'Maxma 14', an interspecific hybrid between P. maha$l e b \times P$. avium was closer to ' $P$. avium'. 'Gisela 5', an interspecific hybrid between $P$. cerasus $\times P$. canescens,

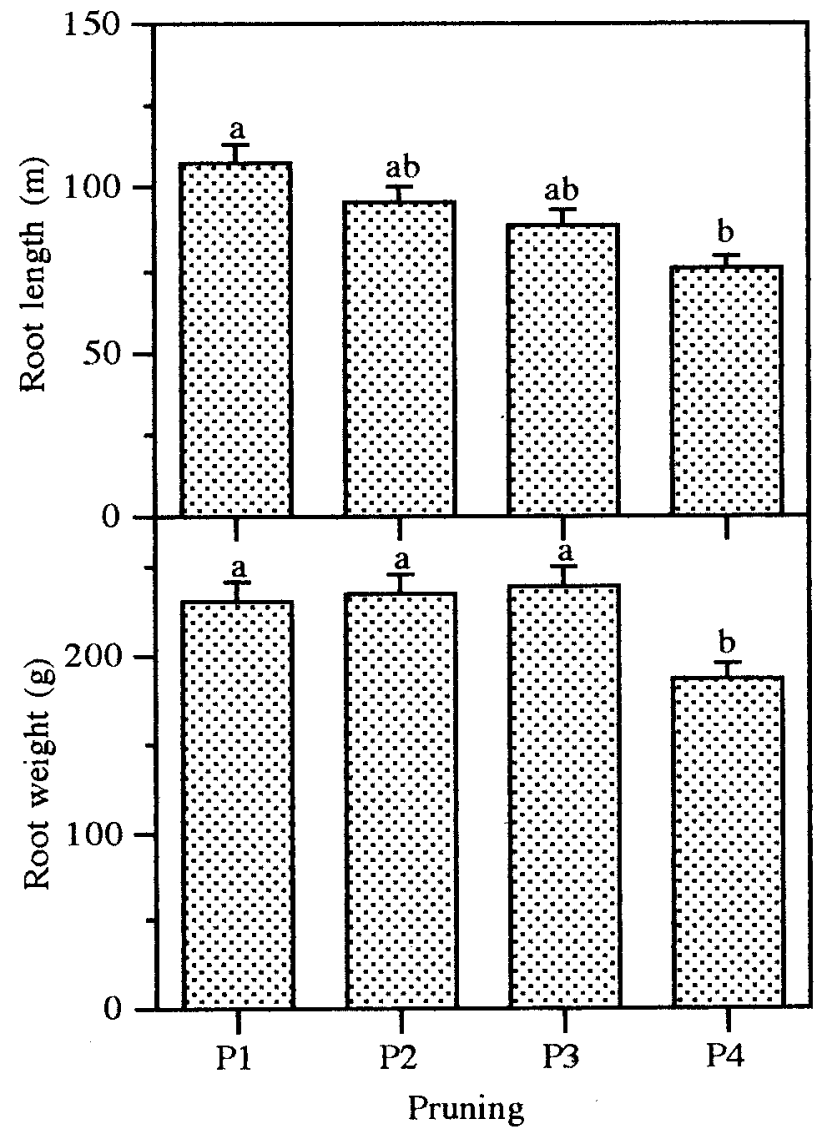

FIG. 2

Root system weight and length of cherry rootstocks, affected by pruning severities (P1 to P4). The columns are the means $(n=24)$ and vertical bars represent standard errors. Columns with the same letter are not significantly different at $P<0.05$ (Fisher's test). 
TABLE II

Discriminant Canonical Analysis (DCA $)^{\S}$ between vegetative characteristics of cherry rootstocks, by forward stepwise analysis

\begin{tabular}{|c|c|c|c|c|c|c|c|c|}
\hline Vegetative characteristics & Step & Wilks's Lambda & d.f. 1 & d.f. 2 & $\mathrm{~F}^{\dagger}$ & d.f. 1 & d.f. 2 & $P$-level \\
\hline Canopy fresh weight (CFW) & 1 & 0.181 & 4 & 97 & 110.05 & 4 & 97 & 0 \\
\hline Branch length & 2 & 0.114 & 4 & 96 & 14.07 & 8 & 192 & $4.507 \mathrm{E}-09$ \\
\hline Stem length & 3 & 0.096 & 4 & 95 & 4.52 & 12 & 251.64 & 0.0022 \\
\hline Stem diameter & 4 & 0.081 & 4 & 94 & 4.23 & 16 & 287.81 & 0.0034 \\
\hline Root weight & 5 & 0.072 & 4 & 93 & 2.97 & 20 & 309.40 & 0.0236 \\
\hline No. leaves & 6 & 0.066 & 4 & 92 & 2.15 & 24 & 322.16 & 0.0803 \\
\hline Root length & 7 & 0.063 & 4 & 91 & 1.04 & 28 & 329.53 & 0.3889 \\
\hline
\end{tabular}

${ }^{\S}$ DCA done by STATISTICA program (Statsoft, 1995).

${ }^{\dagger}$ The $\mathrm{F}$ value for a variable indicates its statistical significance in the discrimination between groups.

seemed to have more affinity with 'Edabriz' than 'CAB $11 \mathrm{E}$ '. So, phylogenetic affinity leads to a more vegetative proximity between the species.

\section{Leaf and stem water potential}

Generally, $\psi_{\text {leaf }}$ of the rootstocks was close to zero during the first hours of the morning, but became gradually more negative through the day until early afternoon, recovering thereafter during the night until sunrise, when it reached similar values as before (data not shown). $\psi_{\text {leaf }}$ varied significantly $(P<0.001)$ between the rootstocks and plant spacing but not with pruning treatments. 'Maxma 14' attained the lowest midday $\psi_{\text {leaf }}$ $(-2.28 \mathrm{MPa})$ due to a higher canopy:root weight ratio (2.21), but it also had the higher value of predawn $\psi_{\text {leaf }}$, meaning that this rootstock had a more favourable water status recovery during the night. A different behaviour was observed for 'CAB 11E' (-1.82 MPa) (Figure 4), may be due to its lowest canopy:root weight ratio (0.84). The less negative midday $\psi_{\text {leaf }}$ values observed on ' $\mathrm{CAB}$ $11 \mathrm{E}$ ' and 'Edabriz' (-1.82 and $-1.93 \mathrm{MPa})$, although they had different vigour, being semi-vigorous and dwarfing, respectively, could be related to some phylogenetic affinity (Figure 3).

In general, at $0.25 \times 1.0 \mathrm{~m}$ the rootstocks exhibited lower predawn and midday $\psi_{\text {leaf }}$ (Figure 5). The likely reason for this is that the available soil water is reduced, causing lowered $\psi_{\text {leaf }}$ 'Edabriz' followed a different trend in the predawn period.

Rootstock genotype significantly affected $(P<0.001)$ the predawn and midday stem water potential of the cherry cultivars. Cultivars grafted on ' $P$. avium' and

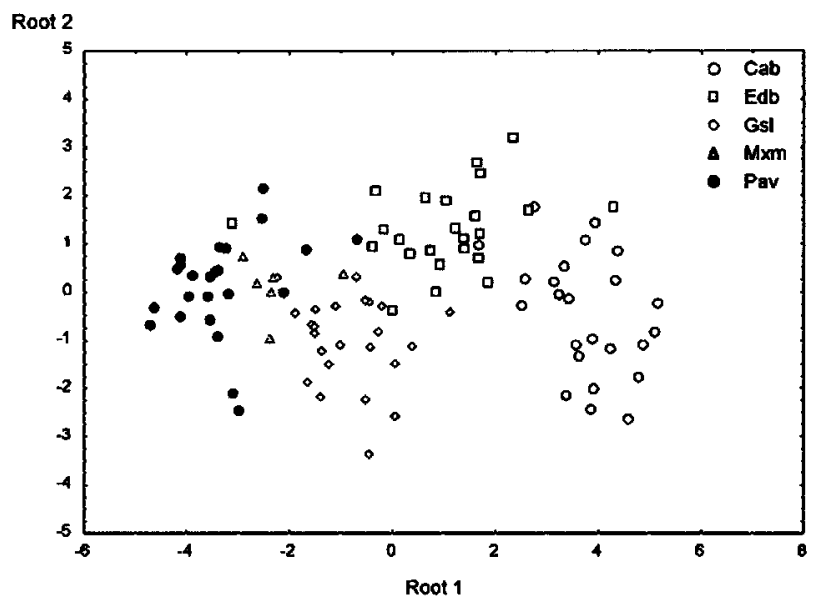

FIG. 3

Discriminant Canonical Analysis (DCA) of vegetative characteristics of cherry rootstocks, by forward stepwise analysis.
'Maxma 14' showed the higher midday $\psi_{\text {stem }},-1.36$ and $-1.42 \mathrm{MPa}$, respectively (Figure 6), so these rootstock genotypes maybe induced drought resistance in the scion. Düring (1994) and Iacono et al. (1998) reported similar observations in grafted grapevines. Cherry cultivars had a better performance (higher $\psi_{\text {stem }}$ ) in these two rootstocks probably due to a deeper root system than the more dwarfing, 'Edabriz' and 'Gisela 5'. Shackel et al. (1997) observed no rootstock effect on midday $\psi_{\text {stem }}$ under fully irrigated conditions, but when irrigation was reduced, trees on 'Colt' rootstock exhibited a more rapid decline in water status than those on ' $P$. mahaleb'. Under these water stress conditions, sorbitol was the soluble carbohydrate present at the highest concentration in 'Colt' and 'Meteor' (Ranney et al., 1991b). Under the same conditions, abscisic acid (ABA) in the xylem sap can increase substantially as a function of reduced soil water availability (Loveys, 1984; Zhang and Davies, 1989). So, several authors and more recently Wilkinson and Davies (2002), concluded there

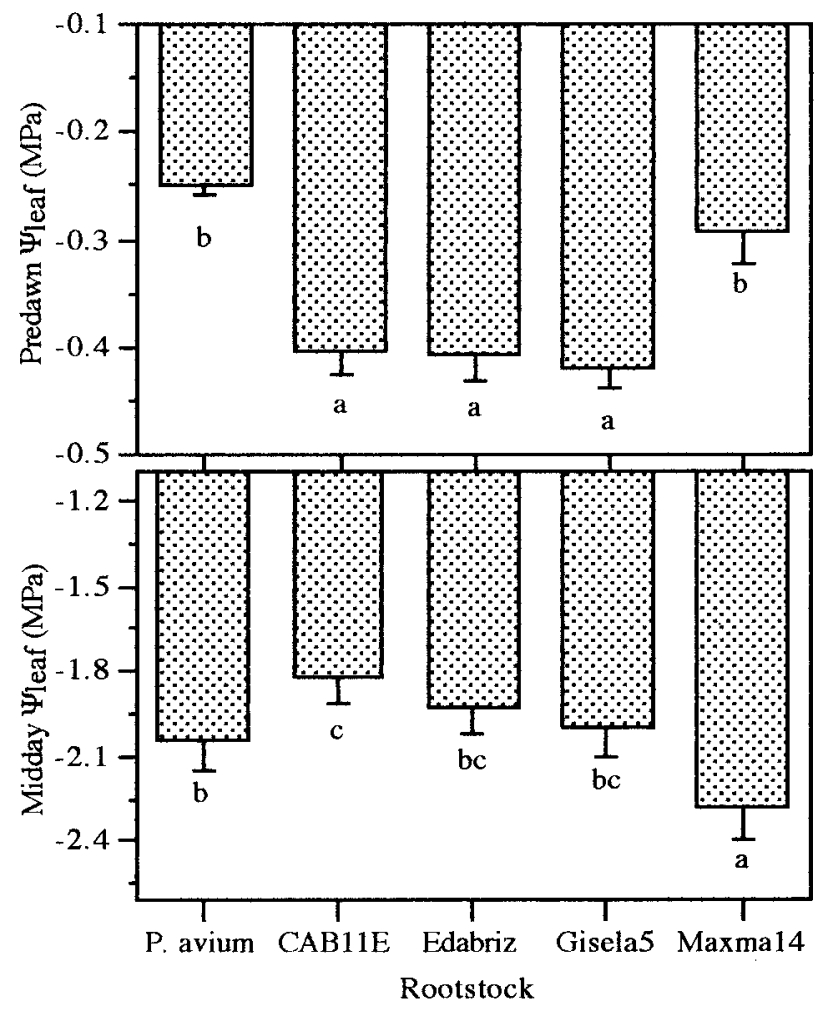

FIG. 4

Leaf water potential of ungrafted cherry rootstocks at predawn and midday. The columns are the mean $(n=3)$ and vertical bars represent standard errors. Columns with the same letter are not significantly different at $P<0.05$ (Fisher's test). 


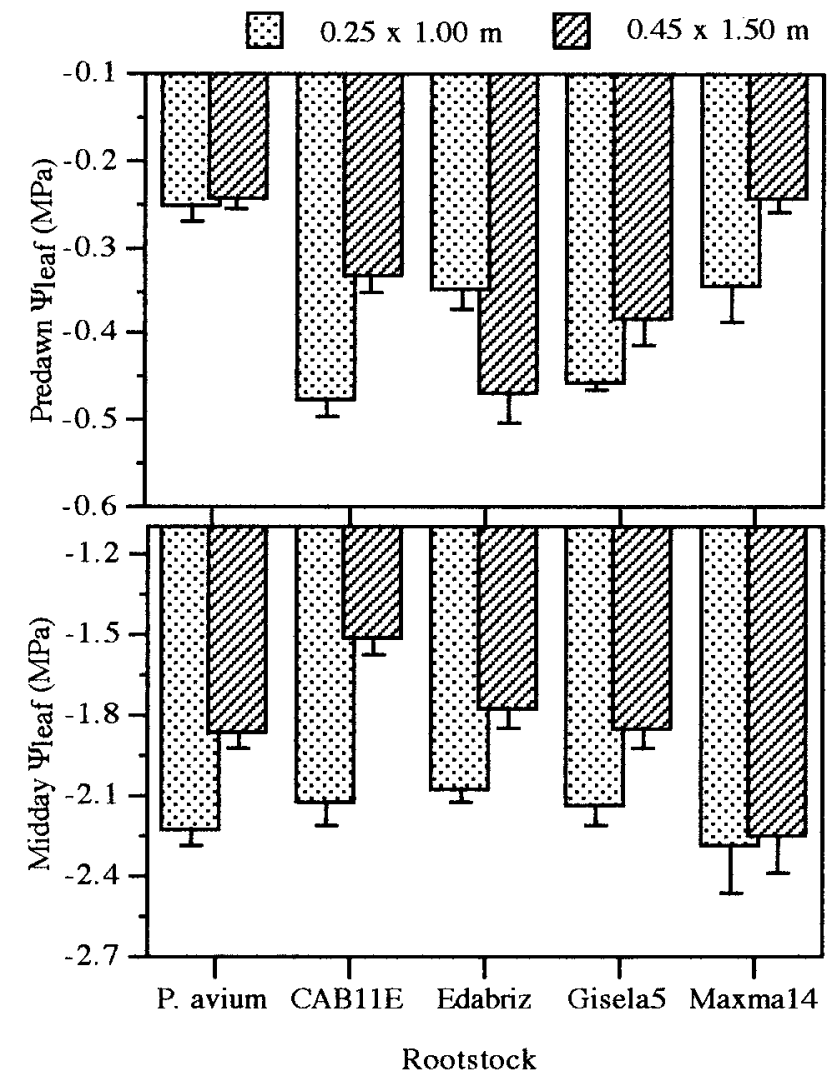

FIG. 5

Leaf water potential of ungrafted cherry rootstocks at predawn and midday affected by plant spacing $(\mathrm{SI}=0.25 \times 1.00 \mathrm{~m}$ and $\mathrm{S} 2=0.45 \times$ $1.50 \mathrm{~m})$. The columns are the means $(n=3)$ and vertical bars represent standard errors.

is now strong evidence that the plant hormone ABA is important in the regulation of stomatal behaviour and gas exchange of droughted plants. Probably, 'P. avium' and 'Maxma 14' have hormonal regulation mechanisms, namely stronger ABA signals that determine the observed results.

Another aspect that could affect $\psi_{\text {leaf }}$ and $\psi_{\text {stem }}$ is the incompatibility observed in the scion-rootstock combination, although we did not detect these symptoms. Schmid et al. (1988), observed that leaves of grafting combinations of $P$. avium $c v$. 'Sam' on ' $P$. cerasus' with symptoms of delayed incompatibility showed less negative $\psi_{\text {leaf }}$ during the daytime, lower transpirations rates, closure of stomata at times of high photosynthetically

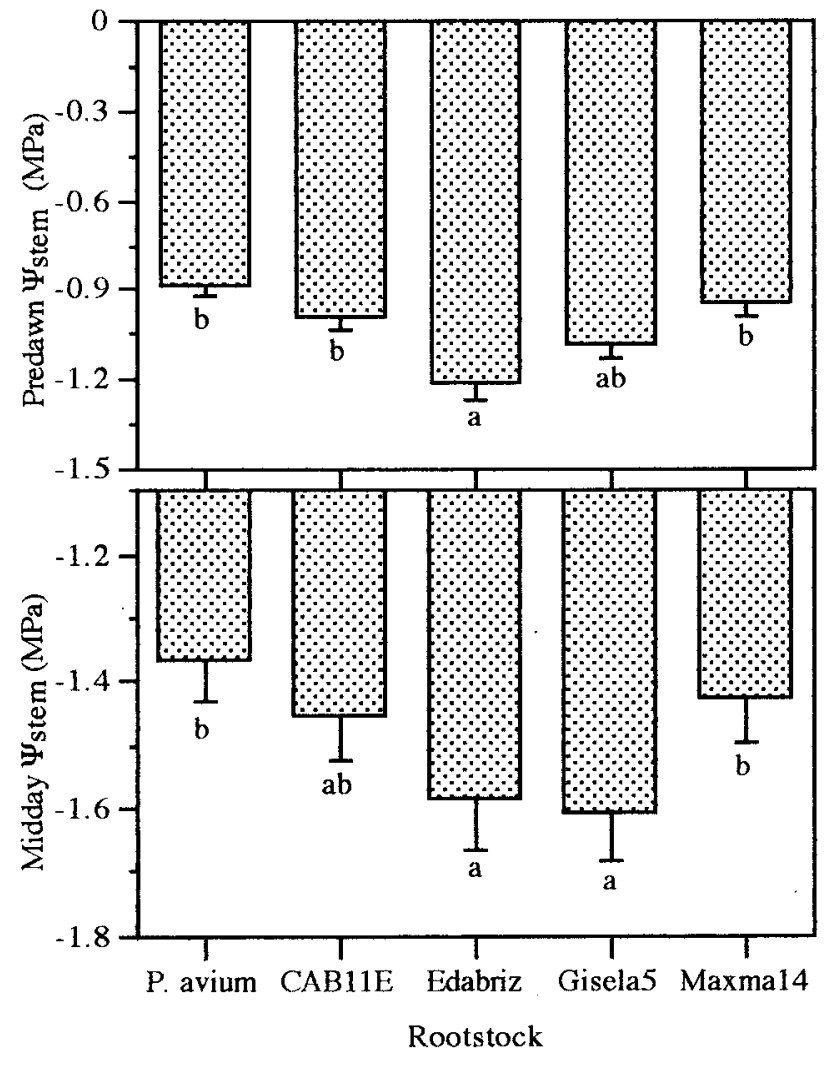

FIG. 6

Stem water potential of grafted cherry rootstocks at predawn and midday. The columns are the means $(n=4)$ and vertical bars represent standard errors. Columns with the same letter are not significantly different at $P<0.05$ (Fisher's test).

active radiation and higher content of carbohydrates, catechins and proanthocyanidins, in spite of their chlorophyll content being lower than that of the leaves of combinations without the symptoms.

\section{CONCLUSIONS}

In some cases, sweet cherry cultivars, grafting to different rootstock genotype increased $\psi_{\text {stem }}$. These results are of interest to horticulture especially in dry areas as they offer the opportunity to increase water-use efficiency and drought resistance by selecting appropriate rootstock varieties.

\section{REFERENCES}

AsAmoah, T. E. O. and AtKinson, D. (1985). The effects of (2RS, 3RS)-1-(4-chlorophenyl)-4, 4-dimethyl-2-(1H-1,2,4 tirazol-1-yl) pentan-3-ol (Paclobutrazol: PP333) and root pruning on the growth water use and response to drought of Colt cherry rootstocks. Plant Growth Regulation, 3, 37-45.

Centritto, M., Magnani, F., Lee, H. S. J. and Jarvis, P. G. (1999) Interactive effects of elevated $\left[\mathrm{CO}_{2}\right]$ and drought on cherry (Prunus avium) seedlings. II. Photosynthetic capacity and water relations. New Phytologist, 141, 141-53.

Chalmers, D. J., Olsson, K. and Jones, T. R. (1983). Water relations of peach trees and orchards. In: Water deficits and plant growth, Vol. 7 (Kozlowski, T. T., Ed.). Academic Press, New York, USA, 197-232.

DÜRING, H. (1994). Photosynthesis of ungrafted and grafted grapevines: effects of rootstock genotype and plant age. American Journal of Enology and Viticulture, 45, 297-9.
EdIN, M. (1993). Porte-greffe du cerisier. Le point sur Tabel $\AA$ Edabriz. Infos-Ctifl, 96, 37-40.

FAust, M. (1989). Physiology of temperate zone fruit trees. John Wiley and Sons Inc., A. Wiley Interscience Publication, USA.

Garnier, E. and Berger, A. (1985). Testing water potential in peach trees as an indicator of water stress. Journal of Horticultural Science, 60, 47-56.

Hair, J., Anderson, R. E., Tatham, R. L. and Black, W. C. (1995) Multivariate data analysis with readings. Prentice Hall International Ed., 4th edition, New Jersey, USA.

Iacono, F., Buccela, A. and Peterlunger, E. (1998). Water stress and rootstock influence on leaf gas exchange of grafted and ungrafted grapevines. Scientia Horticulturae, 75, 27-39.

Larcher, W. (1995). Physiological plant ecology. Third Edition, Springer-Verlag, Berlin, Germany. 
Loveys, B. R. (1984). Diurnal changes in water relations and abscisic acid in field growth Vitis vinifera cultivars III. The influence of xylem-derived abscisic acid on leaf gas exchange. New Phytologist, 98, 563-73.

KAPPEL, F. (1993). Sweet cherry management in Europe. Compact Fruit Tree, 26, 123-4.

Kramer, P. J. (1983). Water relations of plants. Academic Press Inc., New York, USA.

McCutchan, H. and Schackel, K. A. (1992). Stem-water potential as a sensitive indicator of water stress in prune trees (Prunus domestica L.). Journal of the American Society for Horticultural Science, 117, 607-11.

NAOR, A. (1998). Relations between leaf and stem water potentials and stomatal conductance in three field-grown woody species. Journal of Horticultural Science \& Biotechnology, 73, 431-6.

NaOr, A. and WAmple, R. L. (1994). Gas exchange and water relations of field-grown Concord (Vitis labrusca) grapevines. American Journal of Enology and Viticulture, 45, 333-7.

NAOR, A., Klein, I. and Doron, I. (1995). Stem water potential and apple fruit size. Journal of the American Society for Horticultural Science, 120, 577-82.

Ranney, T. G., Bassuk, N. L. and Whitlow, T. W. (1989). Effect of transplanting practices on growth and water relations of 'Colt' cherry trees during reestablishment. Journal of Environmental Horticulture, 7, 41-5.

Ranney, T. G., Bassuk, N. L. and Whitlow, T. W. (1991a). Influence of rootstock, scion, and water deficits on growth of 'Colt' and 'Meteor' cherry trees. HortScience, 26, 1204-7.

Ranney, T. G., Bassuk, N. L. and Whitlow, T. W. (1991b) Osmotic adjustment and solute constituents in leaves and roots of water-stressed cherry (Prunus) trees. Journal of the American Society for Horticultural Science, 116, 684-8.

Schmid, P. P. S., Schmit, E. R. and Zorn, W. (1988). Water relations and some organic compounds in cherry leaves of graftings with delayed incompatibility. Acta Horticulturae, 227, 90-2.

Schmitt, E. R., Duhme, F. and Schmid, P. P. S. (1989). Water relations in sweet cherries (Prunus avium L.) on sour cherry rootstocks (Prunus cerasus L.) of different compatibility. Scientia Horticulturae, 39, 189-200.
Scholander, P. F., Hammel, H. T., Bradstreet, E. D. and Hemmingsen, E. A. (1965). Sap pressure in vascular plants: Negative hydrostatic pressure can be measured in plants. Science, 148, 339-46.

Shackel, K. A., Ahmadi, H., Biasi, W., Buchner, R., Goldhamer, D., Gurusinghe, S., Hasey, J., Kester, D., Krueger, B., Lampinen, B., McGourty, G., Micke, W., Mitcham, E., Olson, B., Pelletrau, K., Philips, H., Ramos, D., Schwankl, L., Sibbet, S., Snyder, R., Southwick, S., Stevenson, M., Thorpe, M., Weinbaum, S. and Yeager, J. (1997). Plant water status as an index of irrigation need in deciduous fruit trees. HortTechnology, 7, 23-9.

SPSS for Windows, Release 8.0 (1997). Hardware secured version Copyright $^{\odot}$ SPSS Inc., 1989-1997. All rights reserved.

STATSOFT, Inc., (1995). STATISTICA for Windows (Computer program manual). Tulsa, OK: Statsoft, Inc., 2300 East 14th Street, OK, 74104-4442, USA.

Thornthwaite, C. W. (1948). An approach toward a rational classification of climate. Geographical Review, 38, 55-94.

TubBs, F. R. (1976). The largely additive relationships of the contributions by scion and by rootstock to the growth of deblossomed compound trees. Journal of Horticultural Science, 51, 435-9.

TubBs, F. R. (1977). The relative influences of fruit clones when present as rootstock or as scion. Journal of Horticultural Science, 52, 37-48.

TubBs, F. R. (1980). Growth relations of rootstock and scion in apples. Journal of Horticultural Science, 55, 181-9.

Webster. A. D. (2001). Rootstocks for temperate fruit crops: current uses, future potential and alternative strategies. Acta Horticulturae, 557, 25-34.

Wilkinson, S. and Davies, W. J. (2002). ABA-based chemical signalling: the co-ordination of responses to stress in plants. Plant, Cell and Environment, 25, 195-210.

Zhang, J. and Davies, W. J. (1989). Abscisic acid produced in dehydrating roots may enable the plant to measure the water status of the soil. Plant, Cell and Environment, 12, 73-81. 